\title{
Література:
}

1. Величко О. Ф., Гриб Д. А., Демідов Б. О., Луханін М. І. Проблемні аспекти інтеграції нетрадиційних видів озброєння до складу перспективної системи озброєння збройних сил держави. Озброєння та військова техніка. 2017. № 3(15). С. 77-83.

2. Cummings M.L. Research Paper Artificial Intelligence and the Future of Warfare [Electronic resource]. International Security Department and US and the Americas Programme, London 2017. 18 p. Режим доступу: https://www.chathamhouse.org/publication/artificial-intelligenceand-future-warfare (дата звернення 25.01.2021).

3. UK Essays. Artificial Intelligence In Military Application Information Technology Essay. November 2013. [Electronic resource]. Режим доступу: https://www.ukessays.com/essays/informationtechnology/artificial-intelligence-in-militaryapplication-informationtechnology-essay.php?vref=1 (дата звернення 25.01.2021).

DOI https://doi.org/10.30525/978-9934-26-046-9-6

\section{ORGANIZATION OF DISTANCE LEARNING SYSTEM AT KHARKIV MEDICAL UNIVERSITY IN AN EMERGENCY SITUATION}

\begin{abstract}
Kocharova T. R.
Senior Lecturer at the Department of Medical and Biological Physics and Medical Informatics

Kharkiv National Medical University

Popov M. Yu.

Student at the III Medical Faculty

Kharkiv National Medical University

Kharkiv, Ukraine

This problem has been relevant in nowadays quarantine measures. In addition, we can evaluate objectively on the example of our university, highlighting the benefits. The history of distance learning began in the 18th century with the development of postal communication between cities in the form of «correspondence».
\end{abstract}


The development of radio and television was accompanied by the creation of popular science and educational programs. In the 1950s, television courses were developed, in particular, the University of Wisconsin in 1965 introduced an educational program for doctors in the telephone format. Later, Coastline Community College was established to offer educational films to universities, and in 1976 the first «virtual college» was opened.

The number of people interested in science and seeking education has grown. In 1960, Donald Bitzer of the University of Illinois created a prototype of the first e-learning system - PLATO, which was designed for students who are in distance learning or living very far away. With the advent of Internet technology, distance education has been given the opportunity to teach online.

During the 1980s and 1990s, educational institutions implemented various programs, such as VSS and CALCampus.[1]

Distance learning, like any other learning system, consists of several parts: substantive and organizational. Thus, a distance learning system is a set of software products and solutions that integrates and automates all or most of the learning processes. To properly organize the learning process, the system must automate the actual functions. For example, to provide teaching materials, to organize interactive interactions of the student with the teacher, to provide control and to form reports.

To properly organize the learning process, the system must automate the actual functions. For example, to provide teaching materials, to organize interactive interactions of the student with the teacher, to provide control and to form reports. The distance learning system should provide the following opportunities:

- Management of all types of education (electronic, full-time and parttime).

- Test of knowledge and skills.

- Analysis of training and evaluation of results.

- Providing content and programs.

- Archive of educational materials.

The system consists of many software modules for simultaneous stay of students, teachers, applicants, programmers, employees of various services and departments of the university. Distance learning is conducted through the University portal.

The teacher upload manuals and a list of recommended references in his personal office. Students are enrolled with login and password issued for access to the teaching materials of the course: texts of textbooks, tasks for 
independent and control works, recommendations for their implementation, the schedule of studying the material, etc.

As the discipline is studied, the student takes tests and exams, which take the form of tests. Teachers, methodologists and specialists of the technical support service by telephone or video, as well as e-mail and communication on the forum of the University give students advice on issues that arose during the educational process.

Consider the specific organization of distance learning on the example of Kharkiv National Medical University.

- Moodle distance learning system. The learning platform is designed to unite teachers, administrators and students in one reliable, secure and integrated system to create a personalized learning environment. It focuses primarily on the organization of interaction between teacher and students, although it is suitable for the organization of traditional distance learning courses, as well as support for face-to-face learning [2]. Moodle has been translated into dozens of languages, including Ukrainian. The system was used in 2014 - in 197, in 2019 - 229 countries, more than 90 thousand officially registered sites running on Moodle.

In the adapted Moodle system of KhNMU there are departments of all faculties and all courses with disciplines. The functionality includes such features as searching for literature sources, communicating with the teacher in web rooms (using the BigBlueButton application, where you can show a presentation and include webcams), download instructions and lecture materials, organization of modular tests with limited access.

- Google Meet and Zoom video services. Provides lectures with a screen demonstration, conference planning, a system of raising hands, chatting, solving various examples using the board.

- The ACS system of KhNMU - the organization of the electronic magazine, the schedule of students and teachers, auditoriums, departments, a possibility of working off, and also there is an informant, the document flow, the working plan and the private page of the student.

- KhNMU repository is an open electronic archive of academic texts, materials of scientific and educational purpose, created by scientists, teachers, other university staff and students.

The repository provides easy and open access to all types of digital content, including text, images, animations, MPEG, textbooks, research papers and more. - Corporate mail system - a system implemented by GMAIL (Google Mail), which creates mail for a separate domain, which provides automatic distribution of invitations to classes, conferences, meetings and other events. 
- The main site of KhNMU and the official telegrams of the Trade Union and KhNMU channels, where important news are posted.

Based on a comprehensive study of distance learning at KhNMU, it can be concluded that it is arranged at a sufficient level and equipped with all special programs. But it is obvious that the relations of participants in distance learning are quite different from the classic interactive model of a modern university teacher - student. And the process of adaptation of students and teachers to distance learning inevitably involved difficulties associated with technical problems of Internet connection, transmission of sound and images, as well as psychological - the lack of face-to-face contact with the teacher and the perception of information in electronic form.

\section{References:}

1. Петькова Ю.Р. История развития дистанционного образования. положительные и отрицательные стороны MOOC. Усnехи современного естествознания. 2015. № 3. с. 199-204. URL: http://natural-sciences.ru/ru/article/view?id=34763 (date access: 20.02.2021).

2. Moodle // Вікіпедія: вільна енциклопедія. URL: https://uk.wikipedia.org/wiki/Moodle (date access: 19.02.2021). 